Jurnal Keperawatan Silampari

Volume 4, Nomor 1, Desember 2020

e-ISSN: 2581-1975

p-ISSN: 2597-7482

DOI: https://doi.org/10.31539/jks.v4i1.1457

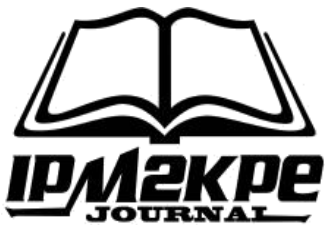

\title{
PROFIL FUNGSI KOGNITIF BERDASARKAN KARAKTERISTIK LANSIA BINAAN SAHABAT LANSIA
}

\author{
Erlina Fazriana \\ Sekolah Tinggi Ilmu Kesehatan Dharma Husada Bandung \\ erlina.fazriana@yahoo.com
}

\begin{abstract}
ABSTRAK
Penelitian ini bertujuan untuk mengetahui profil kognitif berdasarkan karakteristik lansia binaan sahabat lansia Kota Bandung. Metode penelitian ini adalah penelitian deskriptif kuantitatif. Hasil penelitian menunjukkan dari 80 responden lansia, sebagian besar berada pada kategori normal yaitu sebanyak 72 lansia (90\%). Pada lansia yang yang berkategori normal sampai dengan gangguan ringan sebagian besar pada rentang usia 60 - 70 tahun, berjenis kelamin perempuan, pekerjaan ibu rumah tangga, status pernikahan menikah, riwayat kesehatan hipertensi dan aktifitas fisik adalah pekerjaan rumah dan senam, sedangkan untuk lansia yang gangguan kognitif berat usia 78 tahun, jenis kelamin perempuan, status pernikahan janda, pekerjaan sebagai ibu rumah tangga, riwayat kesehatan hipertensi dan aktifitas fisik senam dan pekerjaan rumah. Simpulan, kemampuan kognitif Lansia Binaan Sahabat Lansia di Kota Bandung pada Tahun 2019 sebagian besar masuk kedalam kategori normal dan kemampuan koginitif lansia dengan kategori normal sampai dengan berat sebagian besar lansia melakukan pekerjaan rumah dan senam.
\end{abstract}

Kata Kunci: Karakteristik Lansia, Kemampuan Kognitif, Sahabat Lansia

\begin{abstract}
This study aims to determine the cognitive profile based on the characteristics of the elderly assisted my elderly friends in Bandung. This research method is quantitative descriptive research. The results showed that out of 80 elderly respondents, most were in the normal category, as many as 72 elderly (90\%). The elderly who are categorized as usual to mild disorders are mostly in the age range of 60-70 years, are female, homemakers work, married marital status, medical history of hypertension and physical activity are homework and gymnastics, while for the elderly with disorders cognitive weight, age 78 years, female gender, widowed, marital status, work as a housewife, medical history of hypertension and physical activity, gymnastics and housework. In conclusion, the cognitive abilities of the elderly assisted my elderly friends in Bandung City in 2019 were mostly in the normal category and the cognitive skills of the elderly with typical to severe types; most of the elderly did homework and gymnastics.
\end{abstract}

Keywords: Elderly Characteristics, Cognitive Ability, Elderly Friends 


\section{PENDAHULUAN}

Penduduk di Indonesia mengalami kecenderungan perubahan komposisi jumlah periode usia balita sampai lansia. Sejak tahun 2010 terjadi perubahan bentuk piramida penduduk yang semakin melebar di bagian tengah sehingga ujung piramida yang dimulai usia dari usia 60 tahun ke atas pun semakin melebar. Hal tersebut menyebabkan peningkatan jumlah penduduk lansia makin terlihat sehingga transisi menuju struktur penduduk tua (ageing population) (Sudartini, 2018).

Menurut BPS hasil Susenas 2016 jumlah penduduk lansia Indonesia pada tahun 2010 mencapai 18 Juta $(7,56 \%)$ dan diperkirakan pada tahun 2035 akan mencapai 48 Juta $(15,77 \%)$. Jumlah penduduk lansia di Indonesia tersebar di seluruh provinsi dengan 10 urutan provinsi terbanyak sebagai berikut DIY Yogyakarta (13.69\%), Jawa Tengah (12,09\%), Jawa Timur (11,8\%), Bali (11,2\%), Sumatera Utara (10\%), Sumatera Selatan (9\%), Sumatera Barat (9\%), Jawa Barat (8\%), Lampung (8\%) dan NTB (7,8\%). Populasi lansia Jawa Barat tahun 2015 sebanyak 3.790.351 jiwa dan Kota Bandung sebanyak 185.426 jiwa (Dinkes Kota Bandung, 2015) (Sudartini, 2018).

Menua adalah proses terjadinya perubahan pada semua sistem tubuh salah satunya adalah sistem syaraf. Perubahan pada sistem syaraf mempengaruhi kerja fungsi otak yang menyebabkan penurunan pada memori jangka pendek dan panjang pada lansia sehingga diperlukan upaya - upaya yang mempunyai prinsip penyandian memori jangka pendek dan panjang sehingga dapat mempermudah penyimpanan informasi pada lansia (Andri et al., 2019; Ani et al., 2020).

Kepikunan sering dianggap biasa dialami oleh lanjut usia (lansia) sehingga demensia seringkali tidak terdeteksi, padahal gejalanya dapat dialami sejak usia muda (early on set demensia). Deteksi dini demensia akan mempercepat ditemukannya tanda dan gejala yang dirasakan oleh penderita, sehingga dapat mempersiapkan penderita dan keluarga untuk secara dini mencari pengobatan atau terapi. Demensia yang berat, dapat menyebabkan meningkatnya beban sosial dan ekonomi keluarga, masyarakat, dan negara (Ong, 2017).

Beberapa penelitian yang sudah dilakukan berkaitan dengan status kognitif lansia yaitu tentang "pemeriksaan indeks memori, MMSE (Mini Mental Stase Examination) dan MoCA-Ina (Montereal Cognitive Assestment Versi Indonesia) pada karyawan Universitas YARSI" hasil penelitian indeks memori terhadap 30 karyawan Universitas YARSI, terdapat 11 orang $(36,67 \%)$ menunjukakan penurunan fungsi kognitif dan penurunan indeks memori terutama pada mereka yang berusia diatas 45 tahun (Luthfiana \& Harliansyah, 2019).

DP3APM mempunyai inovasi baru dalam menangani masalah lansia yang dari tahun ke tahun semakin bertambah jumlahnya dan dengan jumlah yang semakin meningkat diharapkan lansia tetap memiliki potensi untuk bisa menjaga kesehatannya dan tetap produktif di usianya. Program inovasi yang dimiliki oleh DP3APM adalah "Bandung Cinta Lansia" dengan programnya adalah program minggu lansia yang diluncurkan mulai tanggal 16 Juli 2017 dengan teknis pelaksanaanya merekrut relawan yang dikenal dengan istilah "Sahabat Lansia". Sahabat lansia tersebar dibeberapa kecamatan dan mereka bertanggung jawab terhadap lansia yang berada di wilayah kecamatan tersebut. Semua lapisan masyarakat dapat menjadi sahabat lansia dengan terlebih dahulu mempunyai komitmen untuk menjadi sahabat lansia dan bersedia meluangkan waktu serta mendaftar via online (Yulius, 2017). 
Tujuan program ini menurut Kepala Dinas DP3APM bapak Dedi Supandi adalah agar lansia tidak kesepian dan mereka merasa berarti di hari tuanya, bisa menikmati kehidupan dan bisa tersenyum. Tidak ada kriteria khusus lansia mana yang harus ditemani atau tidak yang pasti yang sudah berusia 60 tahun ke atas. Jumlah penduduk lansia yang teridentifikasi di kota Bandung sebanyak 263.000 orang (Rachman, 2017).

Penelitian yang dilakukan ada perbedaan dengan penelitian-penelitian sebelumnya, yang mana pada penelitian ini mengidentifikasi profil fungsi kognitif lansia berdasarkan beberapa karakteristik lansia yaitu usia, jenis kelamin, status pernikahan, aktifitas fisik dan riwayat penyakit, sedangkan penelitian sebelumnya yang dilakukan oleh The \& Aisah (2019) hanya penyakit kronis yang diidentifikasi yaitu hipertensi dan diabetes melitus. Hal inipun sesuai berdasarkan pendapat Wreksoatmodjo (2016) bahwa faktor-faktor resiko penurunan fungsi kognitif pada lansia adalah usia, jenis kelamin, riwayat penyakit, akrifitas fisik, genetik, interaksi sosial. Sedangkan penelitian Sauliyusta \& Rekawati (2016) pada lansia di satu wilayah RW dengan tidak melihat aktifitas spesifik yang sering dilakukan lansia.

Penelitian tentang fungsi kognitif pada lansia sebelumya sudah pernah dilakukan, namun penelitian ini dilakukan pada lansia yang masih aktif melakukan senam lansia setiap minggunya dan berasal dari berbagai wilayah kecamatan yang tergabung dalam suatu perkumpulan yaitu sahabat lansia yang dibina oleh DP3APM Kota Bandung.

\section{METODE PENELITIAN}

Penelitian ini merupakan penelitian jenis penelitian deskriptif kuantitatif. Penelitian dilakukan di Taman Lansia tempat kegiatan senam lansia secara rutin yang diikuti oleh lansia binaan sahabat lansia dinas DP3APM. Jumlah lansia dalam sampel penelitian yang dilakukanadalah 80 orang. Sampel pada penelitian ini menggunakan metode probability sampling. Metode pengumpulan data dalam penelitian ini menggunakan tes wawancara.

Penelitian dibantu pewawancara pengumpul data oleh mahasiswa tingkat IV sebanyak 8 mahasiswa yang sebelumnya dilakukan persamaan persepsi tentang cara melakukan tes wawancara dengan instrumen MMSE, kemudian mahasiswa dilatih untuk mempraktekkan sehingga mahasiswa dinyatakan mampu melakukan pengukuran sebelum datang ke responden. Tahap ini dilakukan dengan tujuan menyamakan pengetahuan dan kemampuan mahasiswa dengan peneliti. Peneliti dan mahasiswa melakukan wawancara tentang penilaian kemampuan kognitif dengan instrumen Mini Mental State Examination (MMSE). Hasil kemudian dinilai, dan akan didapatkan skor total kemudian diinterpretasi sesuai jumlah skor.

\section{HASIL PENELITIAN}

Tabel. 1

Gambaran Kemampuan Kognitif Lansia Binaan

Sahabat Lansia

\begin{tabular}{ccc}
\hline Kemampuan Kognitif & F & $\%$ \\
\hline Normal & 72 & 90,00 \\
Gangguan Ringan & 7 & 8,75 \\
Gangguan Berat & 1 & 1,25 \\
\hline Total & 80 & 100,00 \\
\hline
\end{tabular}


Berdasarkan tabel 1 hasil penelitian menunjukan kemampuan kognitif lansia binaan sahabat lansia sebagian besar dengan kategori normal sebanyak 72 orang (90\%).

Tabel. 2

Gambaran Kemampuan Kognitif Berdasarkan Karakteristik Lansia Binaan Sahabat Lansia

\begin{tabular}{|c|c|c|c|c|c|c|}
\hline \multirow{2}{*}{$\begin{array}{c}\text { Kategori } \\
\text { Karakteristik }\end{array}$} & \multicolumn{2}{|c|}{ Normal } & \multicolumn{2}{|c|}{ Ringan } & \multicolumn{2}{|c|}{ Berat } \\
\hline & $\mathrm{f}$ & $\%$ & $f$ & $\%$ & $\mathrm{f}$ & $\%$ \\
\hline \multicolumn{7}{|l|}{ Jenis Kelamin } \\
\hline Laki-laki & 6 & 8,3 & 1 & 14,3 & 1 & 100 \\
\hline Perempuan & 66 & 91,7 & 6 & 85,7 & & \\
\hline \multicolumn{7}{|l|}{ Umur } \\
\hline 60-70 tahun & 69 & 95,8 & 6 & 85,7 & 1 & 100 \\
\hline $71-90$ tahun & 3 & 4,2 & 1 & 14,3 & & \\
\hline \multicolumn{7}{|l|}{ Status Pernikahan } \\
\hline Menikah & 64 & 88,9 & 3 & 42,9 & 1 & 100 \\
\hline Janda & 8 & 11,1 & 4 & 57,1 & & \\
\hline \multicolumn{7}{|l|}{ Pekerjaan } \\
\hline IRT & 54 & 75,0 & 4 & 57,1 & & \\
\hline Pensiunan & 17 & 23,6 & 2 & 28,6 & 1 & 100 \\
\hline Wiraswasta & 1 & 1,4 & 1 & 14,3 & & \\
\hline \multicolumn{7}{|l|}{ Riwayat Kesehatan } \\
\hline Hipertensi & 46 & 63,9 & 5 & 71,4 & & \\
\hline Gastritis & 22 & 30,5 & 2 & 28,6 & & \\
\hline DM & 1 & 1,4 & & & 1 & 100 \\
\hline Kolesterol & 1 & 1,4 & & & & \\
\hline Tidak ada Gejala & 2 & 2,8 & & & & \\
\hline \multicolumn{7}{|l|}{ Aktifitas Fisik } \\
\hline $\begin{array}{l}\text { Pekerjaan Rumah } \\
\text { (mencuci,dll),Senam }\end{array}$ & 57 & 79,2 & 5 & 71,4 & & \\
\hline $\begin{array}{l}\text { Pekerjaan Rumah } \\
\text { (mencuci,dll),Senam, mengaji }\end{array}$ & 11 & 15,3 & 2 & 28,6 & 1 & 10 \\
\hline $\begin{array}{l}\text { Senam, Jalan-jalan } \\
\text { Sall }\end{array}$ & 4 & 5,5 & & & & \\
\hline Total & 72 & 100 & 7 & 100 & 1 & 100 \\
\hline
\end{tabular}

Berdasarkan tabel 2 tentang karakteristik responden menunjukkan berdasarkan kemampuan kognitif lansia dengan kategori normal sebanyak 72 orang dengan karakteristik 66 orang $(91,7 \%)$ berjenis kelamin perempuan, usia rentang $60-70$ tahun sebanyak 69 orang $(95,8 \%)$, status pernikahan menikah sebanyak 64 orang $(88,9 \%)$, pekerjaan ibu rumah tangga (IRT) sebanyak 54 orang (75\%), riwayat kesehatan hipertensi sebanyak 46 orang $(63,9 \%)$ dan aktifitas fisik yang dilakukan oleh responden adalah pekerjaan rumah sehari-hari seperti mencuci, memasak, menyapu dll serta senam sebanyak 57 orang $(79,2 \%)$.

Untuk kategori gangguan kognitif ringan terdapat jumlah lansia sebanyak 7 orang dengan karakteristik berjenis kelamin perempuan 6 orang $(85,7 \%)$, rentang usia $60-70$ tahun terdapat 6 orang $(85,7 \%)$, status pernikahan janda sebanyak 4 orang $(57,1 \%)$, pekerjaan sebagai ibu rumah tangga sebanyak 4 orang $(57,1 \%)$, riwayat kesehatan hipertensi 5 orang $(71,4 \%)$ dan aktifitas fisik yang dilakukan pekerjaan rumah dan senam 5 orang $(71,4 \%)$. 
Untuk kategori gangguan kognitif berat ada 1 orang yang mana karakteristiknya adalah jenis kelamin perempuan, usia 78 tahun, status perkawinan janda, pekerjaan ibu rumah tangga, riwayat kesehatan hipertensi dan aktifitas fisiknya melakukan pekerjaan rumah dan senam.

\section{PEMBAHASAN}

Hasil analisa dari penelitian yang sudah dilakukan menunjukan sebagian besar lansia binaan sahabat lansia yang rutin melakukan kegiatan senam hari Kamis di Taman Lansia mempunyai kemampuan kognitif yang masih normal sebagian besar adalah berjenis kelamin perempuan, status pernikahan sudah menikah, pekerjaan ibu rumah tangga (IRT), memiliki rriwayat kesehatan hipertensi dan aktifitas fisik yang dilakukan oleh responden adalah pekerjaan rumah sehari-hari seperti mencuci, memasak, menyapu dll serta senam. Hasil penelitian tersebut menggambarkan bahwa walaupun proses penuaan pada setiap individu itu berbeda-beda, namun sesuai teori penuaan maka setiap individu akan mengalami dan melewati siklus secara normal.

Faktor-faktor yang mempengaruhi penurunan kemampuan kognitif adalah usia, jenis kelamin, genetik, riwayat penyakit, aktivitas fisik, Interaksi sosial (Wreksoatmodjo, 2016). Terjadinya penurunan kognitif sesuai dengan pertambahan usia, perempuan beresiko lebih tinggi dibandingkan laki-laki, yang mempunyai resiko penyakit hipertensi, DM, obesitas, dan gangguan nutrisi, genetik alzheimer, tingkat aktivitas fisik yang kurang dan interaksi sosial yang kurang. Faktor-faktor yang mempengaruhi fungsi kognitif lansia adalah perubahan fisik, kesehatan umum, tingkat pendidikan dan lingkungan (Untung et al., 2020).

Pemeriksaan MMSE (Mini Mental Stase Examination) adalah tes yang berlangsung selama 10 menit mencakup bahasa, memori dan kalkulasi. Nilai maximal 30 poin dengan pertanyaan-pertanyaan mencakup orientasi waktu ( 5 poin), orientasi tempat ( 5 poin), registrasi ( 3 poin), perhatian ( 5 poin), mengingat kembali ( 3 poin), bahasa (2 poin), repetisi (1 poin), kemampuan mengikuti instruksi yang kompleks (3 poin). Jika seseorang memiliki nilai MMSE dibawah skor 24, maka kemungkinan orang tersebut menderita demensia atau paling tidak mengalami penurunan fungsi kognitif ( (Luthfiana \& Harliansyah, 2019).

Menurut Wreksoatmodjo (2016) faktor yang mempengaruhi penurunan kognitif dari salah satunya dari segi usia, yang mana setiap pertambahan usia peningkatannya sekitar dua kali lipat setiap pertambahan usia 5 tahun. Hal ini sejalan dengan hasil penelitian yang kemampuan kognitifnya masih normal dalam rentang usia 60-70 tahun dan kemampuan kognitifnya mengalami gangguan berat ada 1 orang lansia dengan rentang usia 78 tahun.

Untuk karakteristik jenis kelamin didominasi oleh perempuan dari yang kemampuan kognitif normal sampai dengan yang gangguan berat karena pada saat kegiatan senam lansia yang dilakukan secara rutin banyak diikuti oleh lansia berjenis kelamin perempuan. Sesuai dengan penelitian pada dasarnya perempuan lebih cenderung mempunyai resiko menderita demensia lebih besar daripada laki-laki disebabkan karena pada perempuan yang sudah tua terjadi penurunan estradiol secara drastis yang berhubungan dengan alzeimer.

Menurut Wreksoatmodjo (2016) hasil analisa status pernikahan untuk kategori normal sebagian besar masih berstatus menikah, untuk yang mengalami gangguan kognitif ringan hampir setengahnya berstatus janda dan begitupun yang mengalami gangguan kognitif berat. Hal ini berkorelasi dengan seseorang yang berpartisipasi secara 
aktif dalam interaksi sosial seperti kontak mata, keterikatan emosional, dan ikut serta dalam memberikan respon suatu situasi memiliki kemampuan kognitif yang baik. Asumsinya lansia yang masih mempunyai pasangan dan aktif secara emosional dan selalu berinteraksi setiap hari dengan pasangan dan keluarga akan menunjukkan kemampuan kognitif normal dan akan selalu terjaga baik short term memory dan long term memory nya.

Berdasarkan pekerjaan sebagian besar bermata pencaharian ibu rumah tangga baik dari kategori normal sampai dengan yang gangguan berat, karena di lansia dengan batasan usia lansia lebih dari 60 tahun mereka akan mempuyai waktu luang yang lebih banyak, yang mana anak-anak sudah dewasa dan kegiatan di rumahpun hanya lebih memperhatikan pasangan dan pekerjaan rumah yang sudah biasa dilakukan, sehingga mereka terbiasa dengan membagi waktu antara pekerjaan rumah dan kegiatan senam dll. Untuk yang pekerjaannya pensiunan, lansia yang kemampuan kognitifnya normal lebih besar dibandingkan dengan yang gangguan kognitif ringan dan berat karena asumsinya lansia yang pensiunan, mereka masih aktif mencari informasi dan mengikuti kegiatankegiatan yang ada kaitannya dengan pekerjaannya yang terdahulu.

Hasil analisa dari riwayat kesehatan lansia, menunjukan sebagian besar lansia mengalami hipertensi baik dari kategori normal sampai ganguan kognitif berat, karena berkaitan dengan penyakit degeneratif. Beberapa penyakit yang menjadi faktor resiko demensia adalah hipertensi, aritmia jantung, diabetes mellitus, payah jantung, penyakit hiperkolesterol, obesitas dan gangguan nutrisi (The \& Aisah, 2019). Hal ini menunjukkan dengan sebagian besar riwayat kesehatan hipertensi lambat laun akan mempengaruhi kemampuan kognitif lansia dan kemungkinan akan bergeser ke gangguan kemampuan kognitif yang lebih parah bila tidak dilakukan pencegahan, yang mana salah satunya dengan selalu memberikan fasilitas kepada lansia untuk selalu aktif melakukan kegiatan yang melatih kemampuan koordinasi dan konsentrasi, seperti senam dan stimulasi yang lain.

Untuk karakteristik aktifitas fisik yang kemampuan kognitifnya normal sebagian besar melakukan pekerjaan rumah sehari-hari seperti mencuci baju, memasak, menyetrika, menyapu dll, selain itu mereka juga menyempatkan waktunya untuk rutin melakukan senam setiap hari Kamis. Sebagian kecil ada juga yang selain melakukan pekerjaan rumah dan senam, mereka rutin mengikuti pengajian. Tingkat aktivitas fisik yang tinggi dan rutin serta berkesinambungan mempunyai hubungan dengan kemampuan kognitif. Aktivitas fisik diduga menstimulasi faktor tropik dan neuronal growth yang kemungkinan akan menghambat penurunan kemampuan kognitif. Aktivitas fisik dapat meningkatkan vaskularisasi di otak dan peningkatan level dopamine (Wreksoatmodjo, 2016).

Untuk aspek kognitif yang diukur pada penelitian ini, sebagian besar lansia sebanyak 47 Orang $(65,3 \%)$ dengan kategori normal mengalami penurunan pada aspek perhitungan dan kalkulasi. Untuk lansia dengan kategori gangguan kognitif ringan mengalami penurunan pada aspek kalkulasi, mengingat dan orientasi waktu, sedangkan pada lansia dengan gangguan kognitif berat mengalami penurunan pada semua aspek terutama kalkulasi, orientasi waktu, tempat, registrasi dan mengingat.

Penelitian ini dilakukan pada lansia yang masih aktif melakukan secara rutin senam lansia setiap minggunya dan sebagian besar lansia dalam kategori fungsi kognitif normal. Hasil penelitian ini sejalan dengan penelitian yang dilakukan oleh Djajasaputra \& Halim (2019) tentang fungsi kognitif lansia yang beraktifitas kognitif rutin dan tidak rutin dengan hasil menunjukkan adanya perbedaan kognitif semua aspek antara lansia 
yang beraktifitas rutin dan tidak rutin. Begitupun dalam penelitian yang dilakukan oleh Sauliyusta \& Rekawati (2016) tentang aktifitas fisik mempengaruhi fungsi kognitif lansia dengan hasil adanya hubungan yang signifikan $(\mathrm{p}=0,000 ; \alpha=0,05)$ didominasi pada lansia perempuan yang berusia 60-74 tahun, tidak lulus SD/tidak lulus sekolah, masih berstatus menikah, mempunyai penyakit kronis.

\section{SIMPULAN}

Kemampuan kognitif lansia binaan sahabat lansia di Kota Bandung pada tahun 2019 sebagian besar masuk kedalam kategori normal. Kategori normal dan gangguang kognitif ringan sebagian besar lansia berusia 60-70 tahun, sedangkan lansia yang berusia 78 tahun masuk kedalam kategori kognitif berat . Lansia berjenis kelamin wanita dan sebagian besar menjadi ibu rumah tangga masuk kedalam kemampuan kognitif kategori normal sampai dengan berat. status perkawinan lansia menjadi salah satu faktor masuk kedalam kategori normal bagi lansia yang masih mempunyai pasangan, sedangkan untuk gangguan kognitif ringan sampai dengan berat pada fungsi kognitif lansia yang mempunyai status janda.

Rata-rata kemampuan kognitif lansia dengan kategori normal sampai dengan berat sebagian besar lansia mempunyai riwayat kesehatan hipertensi. Dan kemampuan koginitif lansia dengan kategori normal sampai dengan berat sebagian besar lansia melakukan pekerjaan rumah dan senam.

\section{SARAN}

Diharapkan bagi peserta lansia binaan sahabat lansia untuk tetap melakukan senam lansia secara rutin dan lebih banyak lagi mengikuti kegiatan selain senam lansia yang diselenggarakan oleh DP3APM ataupun kegiatan secara pribadi.

\section{DAFTAR PUSTAKA}

Andri, J., Karmila, R., Padila, P., Harsismanto, J., \& Sartika, A. (2019). Pengaruh Terapi Aktivitas Senam Ergonomis terhadap Peningkatan Kemampuan Fungsional Lansia. Journal of Telenursing, 1(2), 304-313. https://doi.org/https://doi.org/10.31539/joting.v1i2.933

Ani, T., Faridah, A., \& Puji, P. (2020). Pengaruh Memory Training terhadap Fungsi Kognitif Lansia.Universitas Ngudi Waluyo. http://repository2.unw.ac.id/613/

Djajasaputra, A. D. R., \& Halim, M. S. (2019). Fungsi Kognitif Lansia yang Beraktivitas Kognitif secara Rutin dan Tidak Rutin. Jurnal Psikologi, 46(2), 85101. https://jurnal.ugm.ac.id/jpsi/article/view/33192

Luthfiana, A., \& Harliansyah, H. (2019). Pemeriksaan Indeks Memori, MMSE (Mini Mental State Examination dan MoCA-Ina (Montreal Cognitive Assessment Versi Indonesia) pada karyawan Universitas Yarsi. Jurnal Kedokteran Yarsi, 27(2), 062-068. DOI: https://doi.org/10.33476/jky.v27i2.1116

Ong, P. A. (2017). Pengenalan Dini dan Penatalaksanaan Demensia. https://docplayer.info/48374862-Himpunan-seminat-farmasi-rumah-sakit-jabardr-dr-paulus-anam-ong-sp-s-k-klinik-memori-rs-hasan-sadikin-rs-adventbandung.html

Rachman, L. (2017). Program Bandung Cinta Lansia. www.rmoljabar.com

Sauliyusta, S., \& Rekawati, R. (2016). Aktifitas Fisik Mempengaruhi Fungsi Kognitif Lansia. Jurnal Keperawatan, 19(2). http://jki.ui.ac.id/index.php/jki/article/view/463 
Sudartini, S. (2018). Kebijakan Kesehatan Lanjut usia Dinas Kesehatan Provinsi Jawa Barat. https://www.scribd.com/document/421655959/issue-lansia

The, F., \& Aisah, A. (2019). (2019). Profil Fungsi Kognitif Pada Lansia Wilayah Kerja Puskesmas Gambesi. Techno: Jurnal Penelitian, 8(1), 242. DOI: 10.33387/tk.v8i1.1027

Untung, I. U., Untari, D. T. R., \& Untari, S. S. (2020). Perbedaaan Fungsi Kognitif Lansia ditinjau dari Tempat Tinggal. Jurnal Itspku: Profesi (Profesional Islam) Media Publikasi Penelitian, 18(1), 49-54.. https://journals.itspku.ac.id/index.php/profesi/article/view/49/20

Wreksoatmodjo, B. R. (2016). Pengaruh Aktifitas Fisik terhadap Fungsi Kognitif Lansia di Jakarta Barat. Cermin Dunia Kedokteran, 43(1), 7-11. http://www.cdkjournal.com/index.php/CDK/article/view/40/37

Yulius, Y. (2017). Penjelasan Kadis DP3APM Kota Bandung Soal Kegiatan Minggu Lansia. 